\title{
THE EYE-TRACKING USAGE FOR TESTING CUSTOMERS' GAZE ON CONFORMITY MARKS PLACED ON PRODUCTS PACKAGES
}

\author{
Bartosz ORZEL \\ Silesian University of Technology, Faculty of Organisation and Management, Department of Economics and \\ Computer Science; bartosz.orzel@polsl.pl, ORCID: 0000-0003-1506-4798
}

Purpose: The purpose of this article is to perform the idea of eye-tracking method based research, which will allow us to testing the customers gaze on the conformity marks placed on products packages. The aim of this article is to present the possible way of eye-tracking based research method, an experiment the results of which can be used for future research and statistical analyzes.

Design/methodology/approach: To perform the eye-tracking based research, the path and methodology of conducting this research was shown. The basic research method proposed in this paper is experiment, which output should be heat maps with areas, on which people look will be marked. Additionally, the project of short survey, which respondents should complete after eye-tracking examination was presented. The subject of paper is theoretical, but shown methodology, which makes it possible to carry out the same or similar research in reality.

Findings: The main finding of this article is the creation of eye-tracking method based research proposal way, which should allow us to analyze both on conformity marks gazing by customers and other elements of packages. Additionally, the survey conducted after experiment can give researchers an ability to accordance assessment to real conformity marks and other etiquettes/packages marks, on which customers are looking at, and what they think are looking at. It may also allow us obtaining other information, such as: awareness of the types and concept of compliance marks, the voluntary nature of their placement, and also whether consumers care what marks of compliance are marked with the purchased product.

Research limitations/implications: This is the proposition of the way to conduct an experiment. The survey after eye-tracking experiment is created by an author and questions were not prepared with use specific methodology. It is possible to repeat this research with other things placed on products packages and elements of etiquettes.

Practical implications: The practical implication is the ability to develop and use presented path for different things placed on packages, showing on screens etc. It can also leads to conducting other similar researches with usage of this path/way/method.

Social implications: This research may allow us to know, on what conformity and also safety signs customers look most common. These research can also lead to user safety improvement. Originality/value: Using eye-tracking technique in different researches etc. is well known and is not a new method, but in this paper it is transposed especially to conformity marks gazing in specific and practical way of conduct. Basing on literature review the research problem was stated: there are not many or no studies on the use and technical application of eye tracking to study the perception of conformity marks. 
Keywords: eye-tracking, conformity marks, conformity marks observation, oculography.

Category of the paper: research paper, case study.

\section{Introduction}

\subsection{Eye-tracking history}

Oculography (in English often called as an "eye-tracking”) is the technique based on eye gaze movement (Stolecka-Makowska, and Wolny, 2014). It gives information about changing the position of eye and in effect it gives also information about time, directions and area of "scan" by people gaze. It leads to gathering knowledge about the characteristics of person's visual activity (Stolecka-Makowska, and Wolny, 2018; Poole, and Ball, 2004) The beginnings of eye-tracking technique are dated on year 1879, when Louis Emile Javal noticed that people move their eyeballs when they are reading (www.uxbooth.com). Next, Edmund Huey built the first device, which allowed to track the movement of eyeball. It was based on special lens, that needed to be inserted into eye (Wade, 2010; Mohamed et. al, 2007). Those lens were wired to aluminum indicator. Device was running on, in base of regression coefficient (Jacob, and Karn, 2002). The first non-invasive eye-tracking technique was developed in 1901 by Dodge and Cline (Jacob, and Karn, 2002; Płużyczka, 2018). This kind of early "eye-tracking device" was able to react and record horizontal and vertical eye movements and based on registering light reflects from cornea to optical lens system (Płużyczka, 2018; Kapitaniak et. al, 2015; Wade, and Tatler, 2005). This early device was called Photochronograph and was invented, developed and built with a hope to meet the following criteria as much as possible (Dodge, and Cline, 1901):

- the capability of operating under normal conditions of binocular vision,

- capability of both eyes registration simultaneously,

- measurement unit should be 1 dioptric or less,

- registering device should not have momentum or inertia,

- eyes should not do any additional work during registration process and cannot be exposed, on unusual conditions,

- device should be able to record movements of a large number of eyes without serious inconvenience during and after usage.

The modern eye-tracking systems also uses this or similar kind of "light from cornea to optical camera lens" solution (Wade, and Tatler, 2005; Gao et al., 2012). In the year 1935 Guy T. Buswell conducted an important to eye-tracking history research and published a book titled "How People Look at Pictures: A Study of The Psychology of Perception in Art". In this publication Buswell presented first findings in case of peoples' eye movement while 
they looked at complex scenes (Babcock et al., 2002; Buswell, 1935). After $2^{\text {nd }}$ World War, the major researches in gaze detection were conducting in 1947 by Fitts, Jones and Milton. In the end of 1940s they presented technical reports and films connected to aircraft pilots' instruments gazing during landing. It was beginning of head- mount "mobile" eye-tracking systems, which are use commonly in similar researches nowadays (Mohamed, 2007; Fitts et al., 1950; Gomolka et al., 2020). Due to the wearable kind of eye-tracking equipment, the huge amount of such and similar researches were possible to conduct (Ingram, and Wolpert, 2011).

\subsection{Eye-trackers types and usage}

Nowadays, eye-tracking due to the method of eye movements registering can be listed as: (Duchowski, 2003; Andrychowicz-Trojanowska, 2018; Holmqvist, 2017; He et al., 2014; Kumar, and Krol, 1992):

- electro oculography (EOG)

This method relies on differencies in electric potential around the ocular cavity. This method was especially popular in the 1970s and its application is based on placing electrodes around the eyes. (Young and Sheena, 1975)

- sclerar contact lens/search coil

This method is based on applying a coil of wire to the eye. In the case of human subject, a contact lens or sclerar annulus, which contains the coil. This method is most invasive and requires local anaesthetize of the eye for the experiment duration. Nevertheless, despite of negative effects occurring possibilities after experiment, this is method provides excellent spatial and temporal resolution and also most accurate findings (Murphy et. al., 2001; Robinson, 1963; 1964; Young, and Sheena, 1975; Ditterich, and Eggert, 2001; Eibenberger et al., 2016).

- photo and video-oculography

Video-based eye-trackers are most widely used devices in commercial eye-tracking. It can be invasive or non-invasive. Invasive are in form of head-mounted devices, non-invasive are often called as remote eye-trackers. The image is captured by camera and it will change when eye or eyes move. It is based on lights reflected from cornea and emitted to the camera (Chennamma, and Yuan, 2013; Wierts, 2007; Muczyński, and Gucma, 2013).

Additionally, eye-trackers can be also listed due to its mobility. Mobile eye-trackers can be useful in marketing researches in shops, paying consumers' attention to packages types researches, trademarks awareness and recognizing etc. Stationary eye-trackers can be useful in more advanced scenery recognizing in example: broadcasts, jingles, advertisements (Babcock, 2002; Dowiasch et al., 2019; Carter, and Luke, 2020; Cottrell, 2016). Due to years of eye-tracking devices production, methods of researches and technical development usage of this technique both in researches and in everyday life were invented and developed. Modern, based on infrared LED lights eye-tracking systems are able to communicate with many PC operating systems via HID interface. It opened the gate of using most features and functions 
of personal computer equipment systems for people, which were unable to use these devices because of paralyze or suffering from diseases related to the central nervous system diseases. Eye-tracking techniques is also use in industry (i.e. ergonomic, engineering, marketing, road supervising), science (i.e. neurology, psychology, informatics) and military (aviation, military optics) (Pilipczuk, 2014; Wąsikowska, 2015).

\subsection{Overview of chosen researches with the eye-tracking technique use in Poland and in the world}

Nowadays, both in the world, such as in Poland in the field of Management Studies, eye-tracking technique is often use in marketing research, especially in the field of customers package interest and in the case of their looking at the etiquettes placed on products (Wąsikowska, 2015; Cottrell, 2016,). The other proposal of eye-tracking use in Management Studies is to connect Management and Computer Sciences and try to use eye-tracking method to create computer-assisted economic information interpretation system (Korczak, and Kaźmierczak, 2016). The similar, topic of researches as in this paper in Poland, but connected to durable goods were performed in the following article: "Consumer perception of compliance marks on durable goods. Dilemmas of eye-tracking research" (Michalska et al., 2018). In 2015, there were 15 articles written by Polish authors in journals connected to Business Research and Poland had $0,64 \%$ of participation in all articles submitted to these journals. From different journals from Business Research in 2015 most articles were submitted to Marketing Science (5), Journal of Marketing (4) and Journal of Marketing Research (4) (Yang, and Wang, 2015).

\section{The Eye-tracking technique based research design for testing customers' gaze on conformity marks}

\subsection{Conducting an experiment}

The process of gaze is built from saccades- very fast eyeballs movement and periods of eyes stabilization- fixations. Parameters, which describe fixations are time, quantity and frequency (Mastalski, 2018).

Performing the $1^{\text {st }}$ stage of research assumes the use of video-based, remote eye tracking system based on infrared light connected to PC computer with accurate software installed. The whole research process is based on "diagnostic" software model with sequence of fixations and saccades video sequence recording ability (Figure 1). 

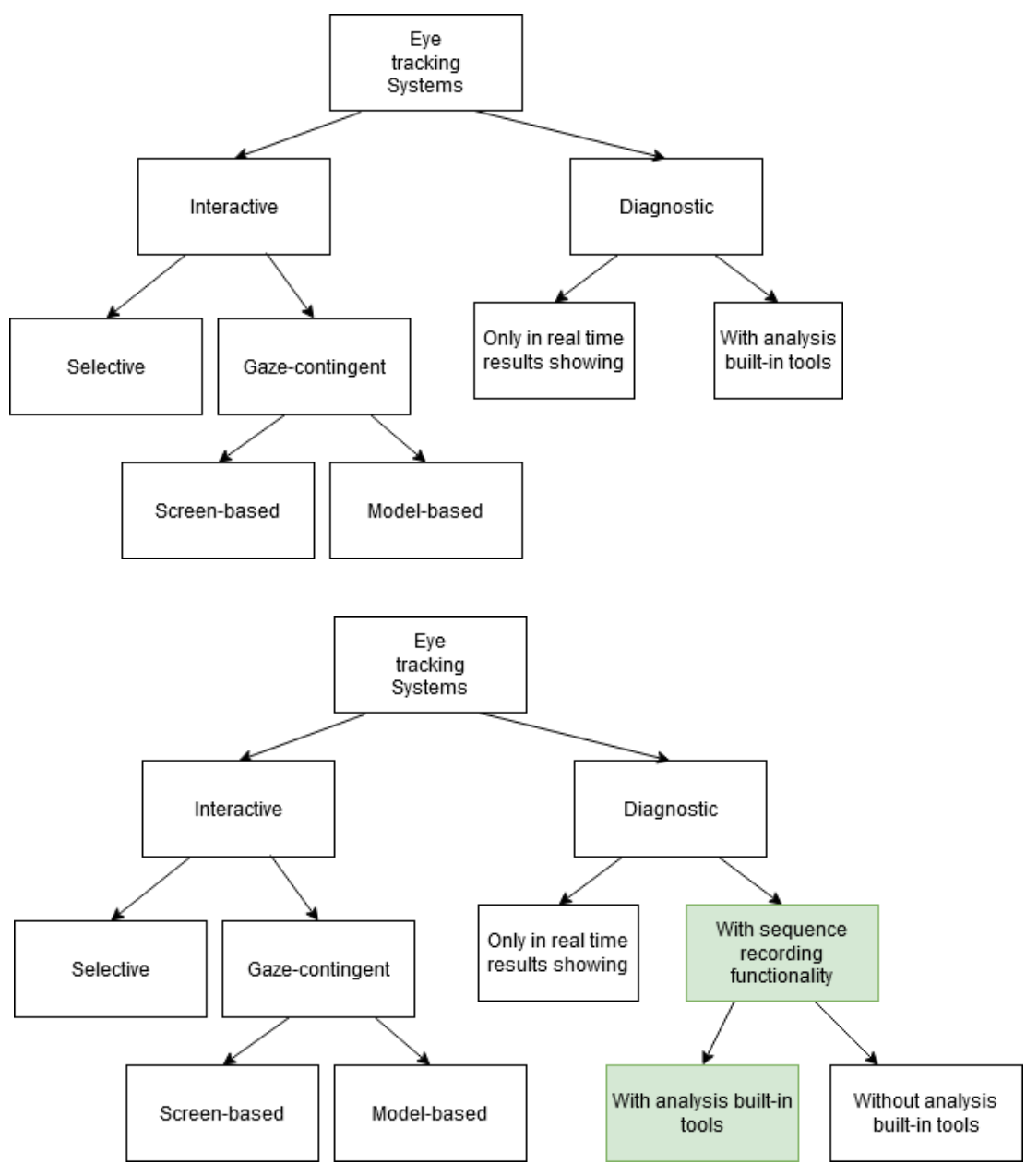

Figure 1. Expanded in base of author's own observations enriched division of eye-tracking software. On the left side original diagram was shown and on the right side with green colour the added type of software use during proposal research was marked. Source: Own work based on: Duchowski, T. (2002). A Breadth-First Survey of Eye Tracking Applications, Copyright 2002 by Behavior Research Methods, Instruments and Computers.

The next step is ask the person, who participate in the research to sit in front of eye-tracker and computer screen. In this moment, a person who operate the computer and eye tracker device should turn on recording and next displays etiquette (Figure 2) or fragment of package in computer screen.
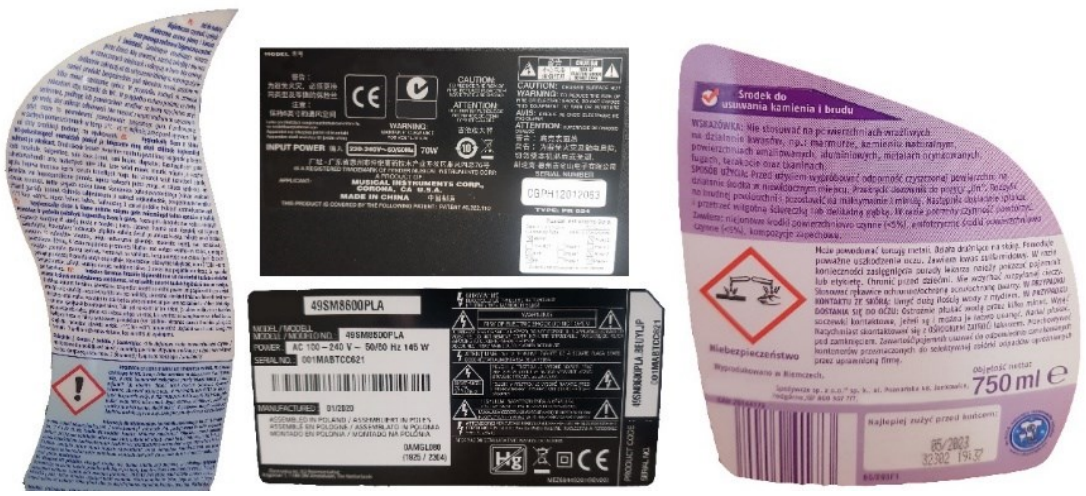

Figure 2. Examples of etiquettes prepared to display during the research with eye-tracking technique based method. Source: own work based on photos taken and prepared by author. 
After record 10-20 seconds sequence, the result should be "the course of gaze" in time. On the video clip there should be marked fixations- red points and the "path" of gaze-saccades (green "fields") (Figure 3).
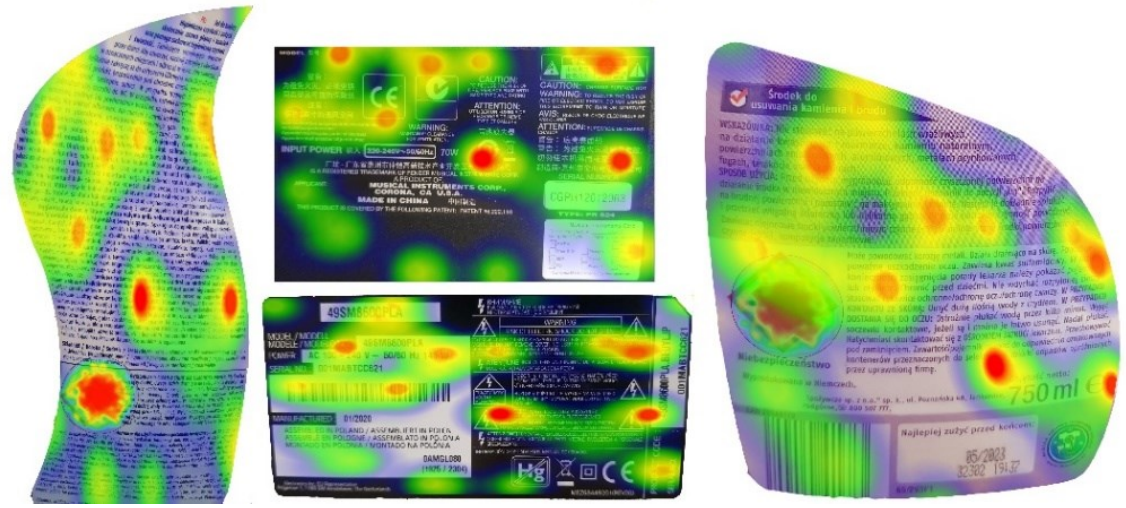

Figure 3. Examples of conducted experiment result. Exampled etiquettes with heat maps marked. Source: own work based on photos taken and prepared by author.

In the next step these heat maps from many research trials can be divided into different types, counted and used for later statistical researches.

\subsection{Survey after eye-tracking examination}

After these steps a person, who participate in research can be asked to complete the short survey. This survey was prepared not only, to obtain an answer, on which elements customer is looking at, but also awareness of the types and concept of compliance marks, the voluntary nature of their placement and whether consumers care what marks of compliance are placed on the purchased product. Below, the survey table contains listed items was presented (table 1).

Table 1.

The project of survey after an eye-tracking examination

\begin{tabular}{|c|c|c|}
\hline QUESTION & \multicolumn{2}{|c|}{ ANSWER } \\
\hline $\begin{array}{l}\text { 1. Do You know the term } \\
\text {,a conformity/compliance } \\
\text { mark"? }\end{array}$ & YES & $\mathrm{NO}$ \\
\hline $\begin{array}{l}\text { 2. Are You aware of } \\
\text { conformity/compliance } \\
\text { marks types appeared on } \\
\text { the packaging of the } \\
\text { labels, which was shown? }\end{array}$ & YES & $\mathrm{NO}$ \\
\hline $\begin{array}{l}\text { 3. Are You aware of the } \\
\text { guidelines connected to the } \\
\text { necessity and voluntary use } \\
\text { of conformity/compliance } \\
\text { marks by manufacturers on } \\
\text { product labels and } \\
\text { packaging? }\end{array}$ & YES & $\mathrm{NO}$ \\
\hline $\begin{array}{l}\text { 4. Do You pay an attention to } \\
\text { the conformity/compliance } \\
\text { marks of the purchased } \\
\text { product? }\end{array}$ & YES & $\mathrm{NO}$ \\
\hline
\end{tabular}


Cont. table 1.

\begin{tabular}{|c|c|c|c|c|c|c|}
\hline $\begin{array}{l}\text { 5. What signs of conformity } \\
\text { Did you pay a particular } \\
\text { attention to, during } \\
\text { viewing their photos? }\end{array}$ & $\begin{array}{c}\text { Danger, } \\
\text { warning } \\
\text { signs }\end{array}$ & $\begin{array}{c}\mathrm{CE} \\
\text { sign }\end{array}$ & $\begin{array}{l}\text { Other } \\
\text { signs }\end{array}$ & $\begin{array}{c}\text { Etiquette } \\
\text { (description } \\
\text { placed by } \\
\text { producer } \\
\text { connected to } \\
\text { composition, } \\
\text { etc.) }\end{array}$ & $\begin{array}{l}\text { Certification } \\
\text { signs }\end{array}$ & $\begin{array}{l}\text { Neither of } \\
\text { them }\end{array}$ \\
\hline \multirow[t]{3}{*}{ METRICS } & \multicolumn{2}{|c|}{ GENDER } & \multicolumn{2}{|c|}{ MALE } & \multicolumn{2}{|c|}{ FEMALE } \\
\hline & \multicolumn{2}{|c|}{ AGE } & Below 20 & \begin{tabular}{|l|l|}
$20-30$ & $30-40$ \\
\end{tabular} & $4-50$ & UP TO 50 \\
\hline & \multicolumn{2}{|c|}{ EDUCATION } & LOWER & $\begin{array}{c}\text { MID- } \\
\text { SCHOOL }\end{array}$ & $\begin{array}{l}\text { HIGH- } \\
\text { SCHOOL }\end{array}$ & $\begin{array}{l}\text { UNIVER- } \\
\text { SITY }\end{array}$ \\
\hline
\end{tabular}

Source: author's own work.

\section{Discussion}

The issues related to the use of the eye tracking technique are known both in Poland and in the world. However, the article presents an innovative, from the scientific literature point of view, attempt to define how the consumer looks at the conformity marks placed on product packaging. First, it is necessary to ask what the perception of conformity marks means. A method of sequences recording was proposed, containing heat maps that show the areas, which are most observed. Due to the possibility of using software that allows recording severalsecond sequences and the time analysis of looking at some elements of the packaging label it is a recommended method of conducting this experiment. The other possibility of usage recording software is choose real-time results showing software. Nevertheless, its only merely a static image without possibility of reproducing the order in which the elements of the label were viewed. The results of the experiment in the form of heat maps allow the broad statistical interpretation based on further statistical researches. The proposed method is based on dividing the types of heat maps according to the viewing time of individual areas of the label and noting the frequency of each of these types in different areas. Exampled statistical researches, which can be taken in base of experiment findings could be:

- Frequency of conformity marks gazing by people.

- Factor analysis for packaging features (requires quantitative data on factors that can influence customers attention).

- Factor analysis for compliance/conformity marks (requires quantitative data on factors that can influence customers attention).

The other part of experiment is survey. Due to this survey it is also possible to obtain data set containing customers' attention paying and awareness of conformity marks information. These all findings can be next use to statistical proceedings. It gives a possibility to conduct next researches connected to previous findings, in example: 
- awareness of conformity/compliance mark term among customers,

- awareness of conformity/compliance marks types,

- awareness of necessity and voluntary conformity marks placing by producers.

The other possibility of use findings from experiments and answers from survey is to conduct research for correlation between looking at conformity/compliance marks and users' safety. On the other hand, conducting both eye tracking and survey researches requires a quite large number of participants. This is particularly important when trying to test the correlation between users' viewing of safety signs and their real safety while using products. Nevertheless, many findings can be learned from presented ideas and also they may contribute to researches connected to safety during different products usage.

\section{Conclusion}

The proposed way of use an eye-tracking technique gives a possibility to gather information about places on etiquettes/packages, on which customers are looking at. Owing to this and findings from survey, which can be conduct after eye-tracking examination it is possible to check, if customers really looked at signs/places, they are thinking. Moreover, such data can be collected in a spreadsheet and serve as the basis for the calculation of various statistics. Exampled path conducted by 1 person was shown below (figure 4).

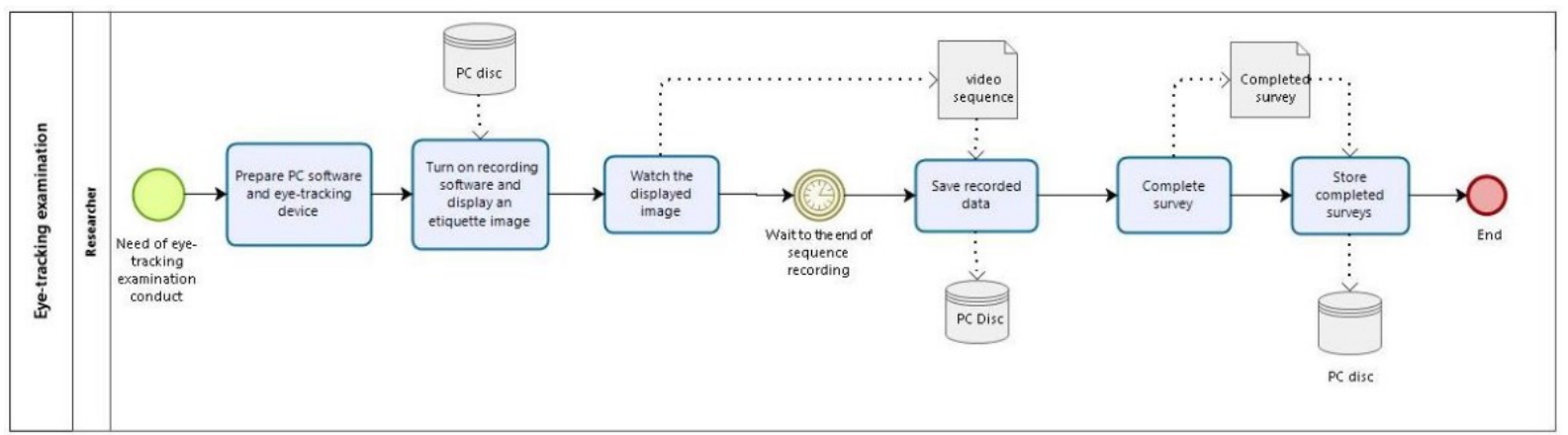

Figure. 4. Exampled path of conducting an eye-tracking self-examination with survey. Source: own work based on BPMN 2.0 methodology.

The path presented in the article is an example and can also be modified and enriched with additional elements. The multitude of possibilities resulting from the eye-tracking method of consumer perception of conformity marks on product packaging makes the use of this method in this scope and context innovative. Also, the use of the results of the experiment itself for various statistical analyzes allowing for a better understanding and determination of the elements that make up the overall perception of the consumer looking at both the product labels and the signs of compliance displayed on them. There are exampled further researches, which can be done: 
- correlation between looking at conformity/compliance marks and users' safety.

- awareness of conformity/compliance mark term among customers,

- awareness of conformity/compliance marks types,

- awareness of necessity and voluntary conformity marks placing by producers,

- actor analysis for packaging features (requires quantitative data on factors that can influence customers attention),

- factor analysis for compliance/conformity marks (requires quantitative data on factors that can influence customers attention).

\section{References}

1. Abdallahi, M., Perreira Da Silva, M., Courboulay, V. (2008). A history of eye gaze tracking, HAL, hal-00215967.

2. Andrychowicz-Trojanowska, A. (2018). Basic terminology of eye-tracking research. Applied Linguistics Papers, 25(2), 123-132.

3. Babcock, J.S., Lipps, M., Jeff, B.P. (2002). How people look at the pictures before, during and after scene capture: Buswell revisited. Proceedings of SPIE - The International Society for Optical Engineering, 10.1117/12.469552.

4. Buswell, G.T. (1936). How People Look At Pictures: A Study Of The Psychology Of Perception In Art. Literary Licensing, LLC, 2012.

5. Carter, B.T., Luke, S.G. (2020). Best practices in eye tracking research. International Journal of Psychophysiology, 155, 49-62.

6. Chennamma, H.R., Yuan, X. (2013) A survey on eye-gaze tracking, techniques. Indian Journal of Computer Science and Engineering (IJCSE), 4(5).

7. Cottrell, D.B. (2016). Comparing Multiple Methods of Eye Tracking for Packaging, thesis. Clemson University.

8. Ditterich, J., Eggert, T. (2001). Improving the homogeneity of the magnetic field in the magnetic search coil technique. IEEE Trans. Biomed. Eng., 10, 1178-85, 10.1109/ 10.951521.

9. Dodge, R., Cline, T.S. (1901). The angle velocity of eye movements. Psychological Review, 8(2), 145-157, 10.1037/h0076100.

10. Dowiasch, S., Wolf, P., Bremmer, F. (2019). Quantitative comparison of a mobile and a stationary video-based eye-tracker. Behavior Research Methods, 0.3758/s13428-01901267-5.

11. Duchowski, A.T. (2002). A Breadth-First Survey of Eye Tracking Applications. BRMIC.

12. Duchowski, A.T. (2003). Eye Tracking methodology: theory and practice. London: Springer-Verlag, 55-65. 
13. Eibenberger, K., Eibenberger, B., Rucci, M. (2016). Design, simulation and evaluation of uniform magnetic field systems for head-free eye movement recordings with sclerar search coils. Annu. Int. Conf. IEEE Eng. Med. Biol. Soc., 247-250, 10.1109/EMBC.2016. 7590686.

14. Fitts, P.M., Jones, R.E., \& Milton, J.L. (1950). Eye movements of aircraft pilots during instrument-landing approaches. Aeronautical Engineering Review, 9(2), 1-6.

15. Gao, D., Yin, G., Cheng, W., Feng, X. (2012). Non-Invasive Eye Tracking Technology Based on Corneal Reflex. Procedia Engineering, 29, 3608-3612; 10.1016/ j.proeng.2012.01.539.

16. Gomolka, Z., Kordos, D., Zeslawska, E. (2020). The Application of Flexible Areas of Interest to PilotMobile Eye Tracking. Sensors, 20(986), 10.3390/s20040986.

17. He, J., Siu, Ch, Chaparro, B., Strohl, J. (2014). Mobile, Eye Tracking in User Experience Design, pp. 255-290, Elsevier Inc.

18. Holmqvist, K. (2017). Eye tracking: A comprehensive guide to methods, paradigms, and measures. Charleston SC, USA: CreateSpace, ISBN-13: 978-1979484893.

19. https://www.uxbooth.com/articles/a-brief-history-of-eye-tracking/, 02.11.2020.

20. Ingram, J.N., Wolpert, D.M. (2011). Enhancing Performance for Action and Perception, Progress in Brain Research, 191, 3-29.

21. Jacob, R.J.K, Karn, K.S. (2002). Eye tracking in human-computer interaction and usability research: Ready to deliver the promises. The Mind's Eye: Cognitive and Applied Aspects of Eye Movement Research, pp. 573-605.

22. Kapitaniak, B., Walczak, M., Kosobudzki, M., Jóźwiak, Z., Borkiewicz A. (2015). Application of eye-tracking drivers testing: A review of research. International Journal of Occupational Medicine and Environmental Health, 28(6), 941-954.

23. Korczak, J., Kaźmierczak, A. (2016). Poszukiwanie wzorców analitycznego myślenia menedżera z wykorzystaniem eye tracking. Przeglad Organizacji, 9, 44-49.

24. Kumar, A., Krol, G. (1992) Binocular Infrared Oculography. Laryngoscope, 102, 367-378.

25. Mastalski, A.S. (2018). Modalność percepcji a podstawy kognitywnej wersologii. Neurolingwistyka Praktyczna, 4.

26. Michalska, A., Maleszka, A., Opiela, A. (2018). Consumer perception of compliance marks on durable goods. Dilemmas of eye-tracking research. Marketing i Rynek, 25(12), 255-264.

27. Muczyńksi B., Gucma, M. (2013). Application of eye-tracking techniques in human factor research in marine operations. Challenges and methodology. Scientific Journals Maritime University of Szczecin, 36(108), 116-120.

28. Murphy, P.J., Duncan, A.L., Glennie, A.J., Knox, P.C. (2001). The effect of scleral search coil lens wear on the eye. Br. J. Ophthalmol., 85, 332-335.

29. Pilipczuk, O. (2014). Technologie eye-tracking w analizie danych medycznych. Roczniki Kolegium Analiz Ekonomicznych. Technologie informatyczne w stużbie zdrowia, 35. Szkoła Główna Handlowa, 323-337. 
30. Poole, A., Linden, J.B. (2004). Eye Tracking in Human-ComputerInteraction and Usability Research: Current Status and Future Prospects. UK: Psychology Department, Lancaster University.

31. Robinson, D.A. (1963). A method of measuring eye movement using a sclerar search coil in a magnetic field. IEEE Trans. Biomed. Eng., 0, 137-45, 10.1109/tbmel.1963.4322822.

32. Robinson, D.A. (1964). The measurement of eye-movement using magnetic induction in a contact lens coil. Biomed. Sci. Instrum., 2(97), 106.

33. Stolecka-Makowska, A., and Wolny, R. (2014). Możliwości zastosowania techniki okulograficznej w ilościowych badaniach marketingowych. Studia Ekonomiczne, 195. Uniwersytet Ekonomiczny w Katowicach, 197-205.

34. Wade, N.J. (2010). Pioneers of eye movement research. iPerception, 1(2), 33-68.

35. Wade, N.J., Tatler, B.W. (2005). The Moving Tablet of The Eye: the origins of modern eye movement research. New York: Oxford University Press.

36. Wąsikowska, B. (2015). Eye tracking w badaniach marketingowych. Zeszyty Naukowe Uniwersytetu Szczecińskiego-Studia Informatica, 863(36), 10.18276/si.2015.36-13.

37. Wierts, R. (2007). Comparison of three eye movement recording techniques for the clinical vestibular practice electrooculography, video oculography and scleral search coils, Master thesis. Eindhoven University of Technology, Department of Applied Physics.

38. Yang, Y., Wang, Ch.-Ch. (2015). Trend of Using Eye Tracking Technology in Business Research. Journal of Economics, Business and Management, 3(4).

39. Young, R.L., Sheena, D. (1975). Eye-movement measurement techniques. Am. Psychol., 30(3), 315-30, 10.1037//0003-066x.30.3.315.

40. Young, R.L., Sheena, D. (1975). Survey of eye movement recording methods. Behavior Research Methods \& Instrumentation, 7, 397-429. 